\title{
EXAMINING ORGANIZATIONAL CULTURE WITH THE OCAI MODEL WITH THE EXAMPLE OF A HIGHER EDUCATION INSTITUTION
}

\author{
Martin GELENCSÉR
}

Department of Management and Leadership Sciences, Institute of Economic Science, Hungarian University of Agriculture and Life Sciences, Campus Kaposvár, Hungary

\section{Bence VÉGVÁRI}

Department of Management and Leadership Sciences, Institute of Economic Science, Hungarian University of Agriculture and Life Sciences, Campus Kaposvár, Hungary

\section{Gábor SZABÓ-SZENTGRÓTI}

Department of Management and Leadership Sciences, Institute of Economic Science, Hungarian University of Agriculture and Life Sciences, Campus Kaposvár, Hungary

Received: 14. September 2020, Reviewed: 29. October 2020, Accepted: 30. November 2020

\begin{abstract}
The Cameron-Quinn (2006) cultural model and the Organizational Culture Assessment Instrument (OCAI) questionnaire based on it are a suitable tool for accurately describing and characterizing the current and ideal organizational culture. The model identifies the characteristics of organizational culture along four dimensions, and its validation has been performed in more than a thousand organizations, including higher education institutions. In the course of our research, we analyzed the organizational culture of a Hungarian university faculty perceived and considered ideal by students using the OCAI model. In our survey, in addition to the identification of organizational culture, we sought to answer the question of whether there is a difference between the characteristics of the current and the ideal organizational culture in the researched higher education institution. Based on the results, it can be concluded that the culture of the organization currently reflects the features of hierarchical culture and clan culture. According to the students, in order to achieve the ideal state, emphasis should be placed on further strengthening the characteristics of the clan culture and reducing the peculiarities of hierarchical culture in the development of organizational culture.
\end{abstract}

Keywords: organizational culture, higher education, Competing Values Framework, OCAI

JEL Classification: A22, I23, I29 


\section{Introduction}

Organizational culture includes the core values, assumptions, interpretations, and approaches that characterize and make an organization unique (Fekete \& Dimény, 2012). In the course of its operation, each organization develops its own unique organizational culture, which largely determines its operation (Bakacsi, 2004; Gregory et al., 2009). All members of the management (Schein, 1992) and staff (Ślusarczyk \& Herbuś, 2014) have a key role in shaping organizational culture. The values of managers and owners define the principles and values of the organization; therefore, organizational culture reflects the goals, visions, spirituality, style and values of the management. One of the most important functions of management is to create, manage, and develop an organizational culture that supports the goals of the organization (Schein, 1992).

Developing the organizational culture of market-oriented companies is of paramount importance as it is closely related to the employer brand, which has a direct impact on the perception of the organization (Cameron \& Quinn, 2006). Culture determines the motivations and performance of internal stakeholders - employees or members of the organization - and the external perception of the organization from the perspective of partners, customers, or potential employees. In market-oriented companies, culture has a fundamental impact on, among other things, competitiveness and market share, attracting, retaining and satisfying employees as well as customers (Deal \& Kennedy, 1982; Gregory et al., 2009; Ojo, 2009; Schwartz \& Davis, 1981; Dano \& Hanulakova, 2016; Senkova et al., 2016).

In Hungary, the higher education system is undergoing a major transformation, the central element of which is the development of a market-oriented operating model. The vision for the sector involves developing an organizational culture characterized by performance orientation. Decision makers have also recognized that a key factor in building competitive organizations is the development of an organizational culture that supports strategic objectives, which is no longer only in the interest of marketoriented companies. The operating condition of state-maintained higher education institutions is to enrol a sufficient number of students, which is inconceivable without an attractive institutional culture (Valent, 2019). Identifying with the culture of a higher education institution not only determines the performance of faculty members and other employees, but also contributes to students' performance and commitment to the organization (Aypay et al., 2012).

In order to create an appropriate organizational culture and to determine the directions of development, it is essential to get to know the current situation in detail - identifying cultural dimensions is an essential condition for cultural development. The complex nature of the concept, as well as the significance of the topic, necessitate that the study of the organizational culture be carried out using a professionally established and validated tool (Cameron \& Quinn, 1999).

We chose Cameron and Quinn's (2006) model as the basis for our survey, because it was preceded by decades of research and development, and the results of more than a thousand organizations show that the questionnaire is a suitable tool for accurately describing current and ideal organizational culture (Balogh et al., 2012), and to characterize and identify the needs of stakeholders involved in shaping organizational culture. Cameron and Quinn (2006) combined the values influencing organizational efficiency into a single model. The Organizational Culture Assessment 
Instrument (OCAI) also makes it possible to determine what values organizations are focusing on in order to increase their efficiency in the long run (Lippert et al., 2015).

The Cameron - Quinn culture model is widely used to examine organizational culture in both the market and public sectors. The model has been used in a number of studies, including public and social institutions (Soroka et al., 2020; Vlaicu et al., 2019), and small and medium-sized enterprises (Jardioui et al., 2019; Saenz Castro et al., 2016; Sanchez-Baez et al., 2020; Wziatek-Stasko et al., 2020). In terms of industries, the model was most commonly used in organizational studies in the energy (Sampaio da Rocha Soares et al., 2018), manufacturing (Hitka et al., 2018; Lorincova et al., 2016), healthcare (Goula et al., 2014; Sopoh et al., 2018), hospitality (Zoghbi-Manrique-de-Lara \& Ding, 2016), mechanical engineering (Luis Leal-Rodriguez et al., 2016), construction (Acar et al., 2014), commerce (Wisniewski \& Leja, 2015), and IT sectors (Oparina, 2014).

Organizational culture of the higher education sector can be identified as an area that lacks sufficient research in Central and Eastern Europe, and the socioeconomic changes of the last decade have also drawn the attention of government and economic actors to the sector. OCAI is also suitable for identifying the peculiarities of organizational culture in higher education institutions, as well as for determining positive organizational changes and development directions. The majority of research in higher education identified university management, faculty members, and other employees as target groups (Aliyu et al., 2020; Berrio, 2003; Debski et al., 2020; Ferreira \& Hill, 2008; Köse \& Korkmaz, 2019; Suderman, 2012). Relatively few studies have been conducted that have assessed students' perceptions of organizational culture.

In order to cover the research gap, the aim of the present study is to examine the organizational culture of a Hungarian university faculty with the involvement of university students, using the OCAI model.

Based on the study of Ujhelyi and Kun (2016), we formulate the following research questions:

1. How can the organizational culture perceived or considered ideal by the students of the examined higher education institution be characterized according to the dimensions of OCAI?

2. Is there a difference between the (considered) ideal and the current culture?

\section{Theoretical background}

\section{Organizational culture}

Organizational culture is a combination of a strategic business perspective and human resource management that results in the appropriate behavior of managers and employees. On the one hand, an organization can be a resource and a carrier of competitive advantage; on the other hand, it can hinder the development of the organization or even be a source of its destruction (Senkova et al., 2016). Defining the concept of organizational culture is extremely difficult, because both the concept of organization and culture divides the views of researchers. Organizational culture is a complex concept that involves many factors.

In Louis's (1981) definition, organizational culture is "a system of interpretations and meanings shared by a particular group of people." Deal and Kennedy (1982) and Cooke and Rousseu (1988), on the other hand, interpret organizational culture as a system of informal rules, common beliefs, and values that 
govern people's thinking and behavior. Hofstede (1980) also approaches the concept from the aspect of values: "culture encompasses value systems, so values are the building blocks of culture. For human communities, culture means what individuality means for individuals... that is, it defines self-identity."

Schein (1991) defines organizational culture as ", a pattern of common basic assumptions discovered or developed by a group while learning to cope with problems of external adaptation and internal integration, and the basic assumptions of which work well enough to be considered valid. They are passed on to new members of the group as the right way to perceive problems, think about them, and feel about them." According to Schwartz and Davis (1981), "organizational culture is a pattern of different beliefs and expectations shared by organizational members. These beliefs and expectations create norms that have a strong influence on the behavior of members of the organization."

Organizational culture is a system of beliefs and beliefs deeply embedded in an organization (Handy, 1981), which the organization has developed in practice over a longer period and by ensuring the cohesion of employees, it ensures the functioning of the organization as well as a sense of organizational identity for its members (Daft, 2001; Kőmúves \& Berke, 2021; Kornmeier \& Schneider, 2006). Thus, an organization is a unit that is formed through the cooperation of several people to achieve a specific goal, has a structure well separated from its environment, its members act according to certain rules, which is also reflected in human behaviors and relationships. Organizational culture includes characteristics that reflect leadership style, strategic plans, organizational atmosphere, remuneration system, and core values of management and the organization (Cameron \& Quinn, 1999). Organizational culture includes, but is not limited to, member behavior, rules of conduct and norms, senior management philosophy, the dominant values they promote and their communication, individual performance appraisal and possible career paths, organizational atmosphere, specific language and jargon, the physical appearance, and logo of the organization (Balogh et al., 2012).

\section{The organizational culture of higher education}

Universities have distinctive characteristics due to their own cultural specificities (Bartell, 2003; Sporn, 1996; Abu Alsuood \& Youde, 2018). In contrast to market-oriented organizations, higher education institutions are often characterized by less clear, difficult-to-measure, and definable values (Bartell, 2003; Baldridge et al., 1978; Birnbaum, 1988; Kosko, 1993). Higher education institutions must meet the interests of both external and internal stakeholders. The group of internal stakeholders includes domestic and foreign students, lecturers, managers, and other employees. External stakeholders include key players in the local community, public authorities, political institutions, businesses, the press, and other organizations. The leaders of higher education institutions have a complex task and a serious responsibility in shaping the organizational culture (Bartell, 2003; Odinokaya et al., 2019).

According to Clark (1980), the cultural structure of higher education is made up of the culture of different disciplines, the culture of teaching and research staff, the faculty and institutional organizational culture, and the general national higher education culture.

According to Bencsik and Marosi (2009), the organizational culture of Hungarian universities is fundamentally based on decentralization and is traditionally hierarchical. The organizational culture of higher education institutions focuses 
on the role (lecturer, researcher, rector, dean, etc.), position (teacher, associate professor, assistant professor, teaching assistant, departmental engineer, study lecturer, etc.), and activity (education or administration, economic or administrative, etc.) in the organization. Continuity and security of operation are ensured by regulation and traditional events (ceremonies, year openings, year closures, conferences, etc.), the decision-making responsibility is shared among the members of the community.

Tierney (1988) draws attention to the shortcomings of cultural research in higher education and emphasizes the need for research in this area as well. Berrio (2003) conducted a research among students at Ohio State University. Based on his results, the characteristics of clan culture prevail in the higher education institution, which coincides with the type of culture preferred by the students. In contrast, in a Slovenian higher education institution, the peculiarities of market culture dominate (Omerzel et al., 2011). Vasyakin et al. (2016) concluded from a survey at Plekhanov Russian University of Economics that the majority of students want to change the hierarchical culture that prevails at the university to an adhocratic or market culture. A study of Christian higher education institutions in the United States found that in most institutions the peculiarities of clan culture can be observed, although in some cases the characteristics of adhocracy culture can also be seen (Obenchain et al., 2004).

Previous research examining organizational culture in higher education has yielded different results based on surveys among students, from which it can be concluded that organizational cultures differ in different countries and on different campuses. As this is an organization-specific concept, organizational development can only be implemented after a local evaluation (Kezar \& Eckel, 2002).

\section{Theoretical framework}

The diversity of research and literature on the topic confirms that academic interest in the topic is significant (Ojo, 2009). However, it is not just the concept of organizational culture that shares the views of researchers. Differences can be detected in the literature regarding the system of tools used in the examination, as well as the purpose of the surveys. Table 1 illustrates the best-known questionnaire-based organizational culture models based on research goals and the levels of culture.

Table 1 Summary table of organizational culture questionnaires

\begin{tabular}{|l|c|c|c|}
\hline Model & Date & Levels of culture & Research goal \\
\hline Allen and Dyer (NDI) & 1980 & attitude & performance \\
\hline Kilmann and Saxton (CGS) & 1983 & attitude & performance \\
\hline Sashkin and Fulmer (OBQ) & 1985 & values & performance \\
\hline Cooke and Lafferty (OCI) & 1986 & attitude & cultural fit \\
\hline Handy & 1986 & values & categorizing \\
\hline Hofstede & 1990 & attitude, values & comparative \\
\hline O'Reilly et al. (OCP) & 1991 & values & cultural fit \\
\hline Ashkanasy et al. (OCP) & 2000 & attitude & comparative \\
\hline Delobbe et al. (ECO) & 2002 & attitude & comparative \\
\hline Robert and Wasti & 2002 & values & comparative \\
\hline GLOBE & 2004 & attitude, values & \\
\hline
\end{tabular}




\begin{tabular}{|l|l|l|l|}
\hline Patterson et al. (OCM) & 2005 & values & comparative \\
\hline Cameron and Quinn (OCAI) & 2006 & values & categorizing \\
\hline
\end{tabular}
Source: Toarniczky (2006)

The aim of our study is to examine the organizational culture of a Hungarian university faculty with the involvement of university students. Among the culture models included in the examined theoretical framework, we found the CameronQuinn culture model to be the most suitable tool for our research goal, as the model categorizes organizational culture in terms of organizational values, on the basis of which the current and considered-to-be-ideal type of culture of the organization can be clearly defined.

The starting point of the Cameron and Quinn (2006) culture model is the operation of organizations and the values that define organizational culture. They defined the four types of organizational culture along two dimensions. The first dimension separates internal orientation, integration, and coherence from the criteria of external orientation and competition. The second dimension distinguishes between flexibility and tight control criteria.

The six key dimensions of the study of organizational culture in the CameronQuinn culture model are:

1. main characteristics of the organization

2. the organizational leadership style

3. people management, employee treatment, work environment

4. the cohesive power of an organization

5. strategic emphases, priority areas of organizational strategy

6. organizational success criteria

Cameron and Quinn (2006) distinguished the following four types of culture along their six key dimensions in their model:

Clan: the organization is like a big family, the employees are friendly; they share a lot with each other. The organization is held together by loyalty, the leaders act as mentors, the development of individuals, openness and trust are considered important. Sensitivity towards customers is defined as success. Clan culture is characterized by teamwork, participation, and consensual decision-making.

Adhocracy: a dynamic, entrepreneurial, creative type of culture that adapts quickly to environmental challenges. The organization is held together by a commitment to innovation and continuous improvement, with an emphasis on rapid growth and adaptation to change. Producing new products and services is a success for an organization. Employees and managers are willing to take risks.

Market: a type of success-oriented culture, where the most important element of efficiency is the results achieved. The cohesive force is victory. The organization focuses primarily on the external environment, with an important role for customers and suppliers. Operation is regulated by market mechanisms. Competitive advantage and efficiency in market culture can be achieved through control, managers are tough competitors, their leadership style is characterized by rigor, determination and performance orientation. Employee behavior also reflects the spirit of competition, and employee relationships are less characterized by trust and cooperation.

Hierarchy: a highly regulated, structured, predictable, and secure type of culture where formal regulations and rules play an important role. The leader is a good coordinator, organizer and supervisor. The long-term goal of the organization is stability, predictability and efficiency. 


\section{Material and methods}

\section{Hypothesis}

Regarding the sample of students examined in our research, it is important to highlight that all respondents are members of Generation Z. This finding is important to our study because literature sources support the fact that different age groups perceive the culture of a given organization differently, which can be traced back to their different value and preference systems (Becton et al., 2014; Meretei, 2017). Generation $\mathrm{Z}$ poses a particular challenge to organizations in terms of commitment (Csehné Papp et al., 2017), as it is a generation that has a hard time identifying with a culture of power and traditional motivational tools are not suitable to increase their commitment. Generation $\mathrm{Z}$ is most committed to an organizational culture characterized by directness, openness, a familiar, friendly atmosphere, and teamwork (Smola \& Sutton, 2002). Based on the following findings, our hypothesis is as follows:

H1: Gen Z university students prefer clan culture due to their generational specificity.

\section{Sample}

The target group of the research is the students of the economic faculty of a higher education institution with defined characteristics, among whom we performed non-random, judgmental sampling. Within the organization of the university, the culture of a given faculty was examined because the entire organization is characterized by a heterogeneous culture and an independently definable organizational culture at different faculties (Hurtado, 2007). During the evaluative sampling, we established the criteria that form the basis of the assessment. As a criterion, it was defined that the student should pursue active undergraduate studies in the field of economics and that at least 30 percent of the population should be included in the study sample. These aspects were defined because the students participating in undergraduate education take part in the life of the faculty in a higher number of hours, typically in the form of full-time education, so they are able to judge the organizational culture of the examined organizational unit better. Based on the criteria that form the basis of the assessment, the size of the population is 265 people. As a result of the sampling, 32.4 percent of the population, a total of 86 students, were included in the sample. Participation in the research was voluntary, and responses were recorded anonymously. Regarding the sample, it can be stated that $69 \%$ of the respondents are female and $31 \%$ are male. 71 per cent of the respondents do not yet have a higher education degree, so they are participating in their first graduate training, while $29 \%$ already have a higher education degree in some field of study.

\section{Data collection tool}

In the research, we used a modified version of the organizational culture model developed by Cameron and Quinn (2006). The original Cameron and Quinn (2006) research model includes six dimensions in order to evaluate each dimension of organizational culture. Based on similar research published in the topic (Ujhelyi \& Kun, 2016), we did not apply the evaluation of success criteria, the sixth dimension of the model, as university students cannot be realistically expected to have a relevant opinion on the success criteria of their higher education institution. Our model 
contained four statements each to be considered in five dimensions, supplemented by demographic questions. The statements in the five dimensions related to one type of culture (clan, adhocracy, market, hierarchy). Students had to distribute one hundred points per dimension between the four statements so that a higher score indicated the greater relevance of the statement. By averaging the scores given to each question, we obtained the values that characterize each culture type. In the questionnaire, respondents had to separately evaluate the organizational culture they currently perceived and the one that they considered ideal.

\section{Data Collection Procedures}

Responses were collected using an online questionnaire, which could be completed independently and/or with expert support. Expert support was provided through an online webinar interface and a personal presence that provided participants with a choice. The questionnaire was tested in advance to determine whether the linguistic modifications made during the translation of the model from English to Hungarian ensured the comprehensibility and feasibility of the questionnaire. Based on the preliminary test, we visually modified the questionnaire and made minor wording clarifications and participants in the testing were not included in the final sample. Subsequently, the head of the faculty authorized data collection, during which the data were recorded anonymously. The data collection lasted for one month, a was implemented in December 2020.

\section{Data analysis}

Due to the nature of the data, descriptive statistical tools were used, and among the parametric tests, the one-sample and paired sample t-tests were used, as a precondition of which we checked the normal distribution of the sample population. One-sample parametric tests are used to verify the correctness of assumptions about a parameter in a given population. To this end, some features of the available sample are compared to some assumed or considered population value (Sajtos \& Mitev, 2007). The results of the statistical tests were considered significant at $\mathrm{p}<0.05$.

\section{Results and discussion}

The importance of organizational culture is increasingly recognized by higher education leaders after large companies. One of the key factors in creating high-performance higher education systems is an awareness-developed organizational culture. Table 2. shows that at a significance level of 5 percent, the mean respondent values deviated from the expected value - of 25 - 5 times for the current culture, and 10 times for the ideal culture. We used a one-sample t-test to measure the significance of the difference.

For the current culture, $2 \mathrm{D}$ and $3 \mathrm{~A}$ took on a higher value compared to the random distribution; and $1 \mathrm{~B}, 2 \mathrm{C}$, and $3 \mathrm{C}$ were lower. Among the dominant characteristics of the examined higher education institution, hierarchy and clan culture reached the highest value, and adhocracy the lowest. In our opinion, the dominance of clan culture can be explained by the fact that the examined higher education institution has a lower number of students compared to the national average, which supports openness and directness between teachers and students, as well as the development 
of a "family" atmosphere. In terms of organizational leadership and operational style, the characteristics of hierarchy and clan culture clearly dominate, and the least emphasis was placed on the characteristics of market culture. In terms of organizational cohesiveness, clan culture also played a key role, with characteristics of adhocracy and market culture reaching lower values compared to a random distribution. In terms of strategic emphases, the characteristics of hierarchy and clan culture also dominate. Overall, it can be stated that currently, the dominant characteristics of the examined higher education institution, organizational leadership, operational style, the cohesive strength of the organization and strategic emphases reflect the features of both hierarchical culture and clan culture.

Table 2 Summary table of organizational culture questionnaires Values of OCAI dimensions and culture types ${ }^{1}(n=86)$

\begin{tabular}{|c|c|c|c|c|c|c|c|c|c|c|c|}
\hline $\begin{array}{l}\text { Dimension, } \\
\text { type of culture }\end{array}$ & & \multicolumn{4}{|c|}{ Current } & \multicolumn{4}{|c|}{ Ideal } & \multicolumn{2}{|c|}{ Difference } \\
\hline Name & $H$ & 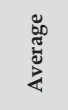 & के & + & 2 & 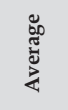 & के & - & 2 & + & 2 \\
\hline \multirow{4}{*}{ 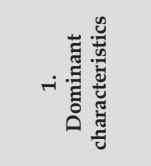 } & A & 26,70 & 14,81 & 0,73 & 0,47 & 31,50 & 16,58 & 2,48 & 0,20 & $-1,72$ & 0,09 \\
\hline & B & 20,43 & 10,19 & $-2,84$ & $0,01^{*}$ & 21,63 & 9,13 & $-2,34$ & $0,02^{*}$ & $-0,73$ & 0,47 \\
\hline & C & 24,25 & 10,71 & $-0,44$ & 0,66 & 24,38 & 11,22 & $-0,35$ & 0,73 & $-0,07$ & 0,94 \\
\hline & $\mathrm{D}$ & 28,63 & 14,23 & 1,61 & 0,12 & 22,50 & 10,50 & $-1,51$ & 0,14 & 2,14 & $0,04^{*}$ \\
\hline \multirow{4}{*}{ 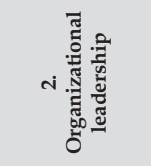 } & A & 27,50 & 11,98 & 1,32 & 0,19 & 35,10 & 16,41 & 3,89 & $0,00^{*}$ & $-2,52$ & $0,02^{*}$ \\
\hline & B & 21,95 & 9,87 & $-1,95$ & 0,06 & 21,60 & 10,59 & $-2,03$ & $0,05^{*}$ & 0,17 & 0,89 \\
\hline & $\mathrm{C}$ & 19,53 & 11,56 & $-3,00$ & $0,00^{*}$ & 16,30 & 11,23 & $-4,90$ & $0,00^{*}$ & 1,66 & 0,10 \\
\hline & D & 31,03 & 12,55 & 3,04 & $0,00^{*}$ & 27,00 & 9,39 & 1,35 & 0,19 & 1,81 & 0,08 \\
\hline \multirow{4}{*}{ 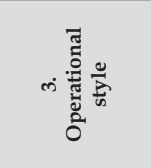 } & A & 29,68 & 9,58 & 3,09 & $0,00^{*}$ & 33,25 & 15,95 & 3,27 & $0,00^{*}$ & $-1,38$ & 0,17 \\
\hline & B & 22,03 & 10,39 & $-1,81$ & 0,08 & 20,38 & 8,80 & $-3,32$ & $0,00^{*}$ & 1,04 & 0,30 \\
\hline & C & 20,18 & 9,71 & $-3,14$ & $0,00^{*}$ & 20,38 & 10,58 & $-2,76$ & $0,01^{*}$ & $-0,15$ & 0,88 \\
\hline & D & 28,13 & 13,30 & 1,49 & 0,15 & 26,00 & 9,95 & 0,64 & 0,53 & 0,82 & 0,42 \\
\hline \multirow{4}{*}{ 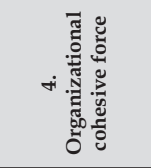 } & A & 27,63 & 12,12 & 1,37 & 0,18 & 32,45 & 15,60 & 3,02 & $0,00^{*}$ & $-2,04$ & $0,05^{*}$ \\
\hline & B & 23,30 & 9,80 & $-1,10$ & 0,28 & 22,80 & 6,98 & $-1,99$ & $0,05^{*}$ & 0,38 & 0,70 \\
\hline & C & 23,25 & 9,47 & $-1,17$ & 0,25 & 21,83 & 10,21 & $-1,97$ & 0,06 & 0,97 & 0,34 \\
\hline & D & 25,83 & 14,69 & 0,36 & 0,72 & 22,93 & 10,50 & $-1,25$ & 0,22 & 1,01 & 0,32 \\
\hline \multirow{4}{*}{ 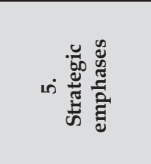 } & A & 24,88 & 16,10 & $-0,05$ & 0,96 & 29,23 & 14,61 & 1,83 & 0,08 & $-1,64$ & 0,11 \\
\hline & B & 23,13 & 8,46 & $-1,40$ & 0,17 & 24,10 & 7,70 & $-0,74$ & 0,46 & $-0,70$ & 0,49 \\
\hline & $\mathrm{C}$ & 24,63 & 14,02 & $-0,17$ & 0,87 & 21,05 & 11,89 & $-2,10$ & $0,04^{*}$ & 2,12 & $0,04^{*}$ \\
\hline & D & 27,38 & 13,96 & 1,08 & 0,29 & 25,63 & 10,93 & 0,36 & 0,72 & 0,66 & 0,51 \\
\hline
\end{tabular}

${ }^{1}$ Explanation: below the current and ideal values, $\mathrm{t}$ is the one-sample $\mathrm{t}$-test, and in the difference column, the paired samples t-test 


\begin{tabular}{|c|c|c|}
\hline $\begin{array}{c}\text { Dimension, type of } \\
\text { culture }\end{array}$ & Current average & Ideal average \\
\hline (A) Clan & 27,28 & 32,31 \\
\hline (B) Adhocracy & 22,17 & 22,10 \\
\hline (C) Market & 22,37 & 20,79 \\
\hline (D) Hierarchy & 28,20 & 24,81 \\
\hline
\end{tabular}

Source: processing by authors

For the ideal culture, the mean of $2 \mathrm{~A}, 3 \mathrm{~A}$, and $4 \mathrm{~A}$ exceeded the expected distribution, and the values of 2B, 2C, 3B, 3C, 4B, and 5C did not reach the expected value. Based on the results, according to the students, it would be ideal for the dominant characteristics of the higher education institution if the characteristics of the clan culture were given even more emphasis and the peculiarities of the hierarchy would be less prevalent. Student opinions also reflect this result in terms of organizational leadership, operational style, organizational cohesiveness, and strategic emphases.

We examined the difference between the current and the ideal culture with paired samples t-test and found the difference to be significant for the following four statements:

„The organization is a very regulated and structured place. People's actions are governed by formal regulations." A lower-than-current and below-average value would be ideal according to the students.

"The leadership style of the organization is characterized by mentoring, support, and care." Based on the results, the current value is also above average, but an even higher value would be ideal.

"The cohesive force of the organization is loyalty and mutual trust. There is a high level of commitment to the organization." Although the current value is also above average, a further increase would be required to reach the ideal state.

"The organization focuses on competitiveness and results. Achieving market leadership is important." Although the current value is lower than average, students would find it even lower ideal.

Overall, it can be stated that the organizational culture of the examined higher education institution is currently mostly characterized by the peculiarities of hierarchy and clan culture. According to the university students surveyed, to achieve the ideal state, emphasis should be placed on strengthening the characteristics of clan culture and reducing the peculiarities of hierarchical culture in the development of organizational culture, which is also illustrated in Figure 1. 


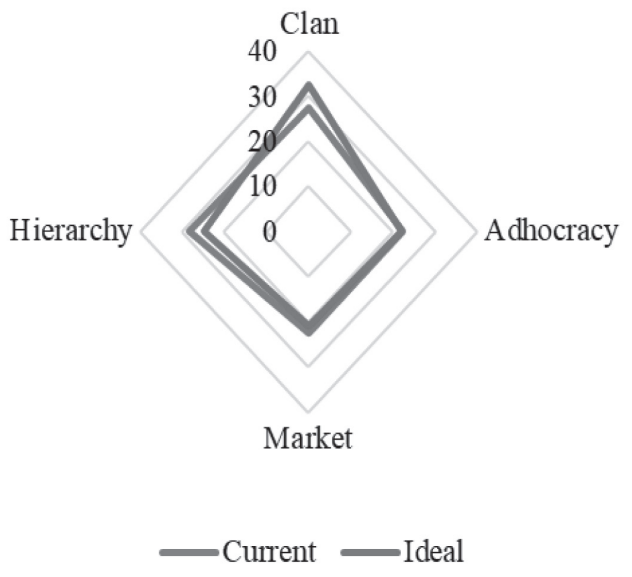

Source: processing by authors

\section{Conclusion}

In the course of our research, we examined the organizational culture of a Hungarian university faculty. Based on the results of the survey, we consider that the study is suitable for determining the organizational culture of the examined higher education institution. Because our research was conducted with the involvement of an organization that had not previously participated in a similar study, the study provides novel research findings. The research helps to shed light on how the most important internal stakeholders of the examined higher education institution, the students think about the ideal organizational culture, revealing the strengths of the current culture and the areas to be developed. In addition, the results help management understand students' thoughts and provide information about student preferences and satisfaction. Our hypothesis formulated at the beginning of the research is supported by the results of the survey, generation $\mathrm{Z}$ university students prefer clan culture the most. Thus, it can be concluded that the younger generation prefers a familiar and open organizational culture not only in the workplace environment, but also in higher education.

Based on the results, it can be stated that there is a significant difference between the current and ideal culture of the higher education institution according to the students. In terms of the current dominant characteristics of the organization, it is more regulated and structured than average, more direct and familiar, but it is less characterized by performance orientation and entrepreneurship. From the point of view of leadership, it can be stated that leadership is mainly characterized by helpfulness and support, and the spirit of competition and performance orientation in leadership style is also below average. In terms of the current operating style of the organization, teamwork and predictability dominate, with less risk-taking and competition. The main components of the cohesive strength of a higher education institution are loyalty, mutual trust and commitment. Among the strategic emphases, permanence 
and stability play a central role, and efficiency, control and smooth operation play an important role.

Based on the results of the study, the following suggestions are made. The management of the higher education institution does not need to intervene in the field of adhocracy and market characteristics during organizational development, as the current and the ideal situation are essentially the same in this respect. However, in developing the organizational culture, it is recommended to focus on further strengthening the clan characteristics and reducing the hierarchical ones. Based on our research, we believe that the organization's leadership should further strengthen openness, mutual trust and immediacy, teamwork, the familiar and supportive nature of the atmosphere, and the role of personal development. In our view, reducing hierarchy can be achieved by loosening the level of rules, regulations, and control, which the management is also encouraged to consider when designing organizational development interventions and strategies.

Within the limits of our research, we have to emphasize that no general statements can be made on the basis of the results, because during our survey we addressed only one group of members of the examined higher education institution, the students. At the same time, the research reports a number of novel results that can be used in the cultural development of Hungarian universities. Further research could be to assess and collide with the views of other internal stakeholders, such as faculty or management, and to involve other higher education institutions in order to formulate proposals for higher education that are even more useful in practice.

The research was supported by the project "Intelligent specialization program at Kaposvár University”, No. EFOP-3.6.1-16-2016-00007.

\section{Bibliography}

1. Acar, P., Kiyak, M., \& Sine, B. (2014). The Relationship Between Organizational Culture and Mobbing: An Application on Construction Companies. Journal of Workplace Behavioral Health, 29(4), 281-298. https:// doi.org/10.1080/15555240 .2014.956929

2. Aliyu, M. O., Akinwale, A. A., \& Shadare, A. O. (2020). Psychological contracts and discretionary behaviour in Nigerian academics. Acta Oeconomica Universitatis Selye, 9(1), 24-44. https:/ / doi.org/10.36007/ Acta.2020.9.1.2

3. Aypay, A., Cekic, O., \& Boyaci, A. (2012). Student Retention in Higher Education in Turkey: A Qualitative Study. Journal of College Student Retention-Research Theory \& Practice, 14(1), 91-116. https:/ / doi.org/10.2190/CS.14.1.e

4. Bakacsi, Gy. (2004). Szervezeti magatartás és vezetés. Aula Kiadó.

5. Baldridge, J. V., Curtis, D. V., Ecker, G., \& Riley, G. L. (1978). Policy Making and Effective Leadership. Jossey-Bass.

6. Balogh, Á., Bogdány, E., Cserháti, G., Csizmadia, T., \& Polák-Weldon, R. (2012). Keresleti-kínálati diszharmónia a szervezeti kultúra tükrében (Demand-supply disharmony in the organizational culture). Vezetéstudomány / Budapest Management Review, 43.

7. Bartell, M. (2003). Internationalization of Universities: A University CultureBased Framework. Higher Education, 45, 43-70. https://doi.org/10.1023/ A:1021225514599

8. Becton, J., Walker, H., \& Jones-Farmer, L. A. (2014). Generational differences in workplace behavior. Journal of Applied Social Psychology, 44. https://doi. org/10.1111/jasp.12208 
9. Bencsik, A., \& Marosi, I. (2009). A „Tudás Templomai” hívők és szerzetesek nélkül? - Avagy tudásmenedzsment a felsőoktatásban. Vezetéstudomány / Budapest Management Review, 40.

10. Berrio, A. A. (2003). An Organizational Culture Assessment Using the Competing Values Framework: A Profile of Ohio State University Extension. Journal of Extension, 41(2).

11. Birnbaum, R. (1988). How Colleges Work: The Cybernetics of Academic Organization and Leadership. Jossey-Bass.

12. Cameron, K. S. \& Quinn, R. E. (1999). Diagnosing and Changing Organizational Culture Based on the Competing Values Framework. Addison-Wesley Publishing.

13. Cameron, K. S., \& Quinn, R. E. (2006). Diagnosing and Changing Organizational Culture: Based on the Competing Values Framework. Jossey-Bass.

14. Chikán, A. (2004). Vállalatgazdaságtan. 3. átdolgozott kiadás. Budapest: Aula Kiadó.

15. Clark, B. (1980). Academic Culture. Higher Education Research Group Institution for Social and Policy Studies. Yale University.

16. Cooke, R., \& Rousseau, D. (1988). Behavioral Norms and Expectations: A Quantitative Approach To the Assessment of Organizational Culture. Group \& Organization Studies, 13, 245-273. https:/ / doi.org/10.1177/105960118801300302

17. Csehné Papp, I., Szabó, K., Schwarczová, L., \& Hajós, L. (2017). Expectations and visions of " $Z$ " generation of university students in relation to the labour market. Acta Oeconomica Universitatis Selye, 6(1), 23-38.

18. Daft, R. L. (2001). Organization Theory and Design. South- Western Publishing.

19. Dano, F., \& Hanulakova, E. (2016). Internationalization of Consultancy Services. Proceedings of 16th international joint conference: central and Eastern Europe in the changing business environment, 76-87

20. Deal, T. E., \& Kennedy, A. A. (1982). Corporate Cultures: The Rites and Rituals of Corporate Life. Addison-Wesley Publishing.

21. Debski, M., Cieciora, M., Pietrzak, P., \& Bolkunow, W. (2020). Organizational culture in public and non-public higher education institutions in Poland: A study based on Cameron and Quinn's model. Human Systems Management, 39(3), 345355. https:/ / doi.org/10.3233/HSM-190831

22. Fekete H., \& Dimény E. (2012). Megfelelő kultúra = kiváló teljesítmény? (Appropriate culture = excellent performance?). Vezetéstudomány - Budapest Management Review, 43(4), 36-47.

23. Ferreira, A. I., \& Hill, M. M. (2008). Organisational cultures in public and private Portuguese Universities: A case study. Higher Education, 55(6), 637-650. https:/ / doi.org/10.1007/s10734-007-9080-6

24. Fralinger, B., \& Olson, V. (2007). Organizational Culture At The University Level: A Study Using The OCAI Instrument. Journal of College Teaching \& Learning (TLC), 4(11), Article 11. https:/ / doi.org/10.19030/tlc.v4i11.1528

25. Goula, A., Kefis, B., Stamouli, A., Pierrakos, G., \& Sarris, M. (2014). Investigation of the organizational culture of general public hospitals. Archives of Hellenic Medicine, 31(4), 452-460.

26. Gregory, B. T., Harris, S. G., Armenakis, A. A., \& Shook, C. L. (2009). Organizational culture and effectiveness: A study of values, attitudes, and organizational outcomes. Journal of Business Research, 62(7), 673-679. https:/ / doi.org/10.1016/j. jbusres.2008.05.021

27. Handy, C. (1981). Understanding organizations. Penguin Books.

28. Heidrich, B. (2017). Szervezeti kultúra és interkulturális menedzsment. Akadémiai Kiadó. 
29. Hitka, M., Lorincova, S., Bartakova, G. P., Lizbetinova, L., Starchon, P., Li, C., Zaborova, E., Markova, T., Schmidtova, J., \& Mura, L. (2018). Strategic Tool of Human Resource Management for Operation of SMEs in the Woodprocessing Industry. Bioresources, 13(2), 2759-2774. https://doi.org/10.15376/ biores.13.2.2759-2774

30. Hofstede, G. (1980). Motivation, leadership, and organization: Do American theories apply abroad? Organizational Dynamics, 9 (1), 42-63. https://doi. org/10.1016/0090-2616(80)90013-3

31. Hurtado, S. (2007). The Study of College Impact. In: Gumport, P. J. (ed.): Sociology of Higher Education: Contributions and Their Contexts. Johns Hopkins University Press.

32. Jardioui, M., Garengo, P., \& El Alami, S. (2019). How organizational culture influences performance measurement systems in SMEs. International Journal of Productivity and Performance Management, 69(2), 217-235. https://doi. org/10.1108/IJPPM-10-2018-0363

33. Kezar, A., \& Eckel, P. D. (2002). The Effect of Institutional Culture on Change Strategies in Higher Education. The Journal of Higher Education, 73(4), 435-460. https://doi.org/10.1080/00221546.2002.11777159

34. Kornmeier, M., \& Schneider, W. (2006). Balanced Management. Erich Schmidt Verlag.

35. Kosko, B. (1993). Fuzzy Thinking: The New Science of Fuzzy Logic. Hyperion.

36. Kőmúves, Zs., \& Berke, Sz. (2021). Labor retention in the domestic SME sector in Somogy county. Régiókutatás Szemle, 6 (1), 66-77. https:/ / doi.org/10.30716/ RSZ/21/1/6

37. Lippert, R., Gaál, Z., \& Kovács, T. (2015). A vezetői szerepek és a szervezeti kultúra hatása a klasztersiker érettségi modelljére. Vezetéstudomány / Budapest Management Review, 46.

38. Louis, M. R. (1981). A cultural perspective on organizations. 2, 246-258.

39. Luis Leal-Rodriguez, A., Ariza-Montes, A., Morales-Fernandez, E. J., \& Eldridge, S. (2016). Assessing the links between organisational cultures and unlearning capability: Evidence from the Spanish automotive components industry. International Journal of Innovation and Learning, 20(4), 422-436. https://doi. org/10.1504/IJIL.2016.10000466

40. Meretei B. (2017). Generációs különbségek a munkahelyen - szakirodalmi áttekintés. Vezetéstudomány - Budapest Management Review, 48(10), 10-18. https:/ / doi.org/10.14267/VEZTUD.2017.10.02

41. Obenchain, A. M., Johnson, W. C., \& Dion, P. A. (2004). Institutional Types, Organizational Cultures, and Innovation in Christian Colleges and Universities. Christian Higher Education, 3(1), 15-39. https://doi. org/10.1080/15363750490264870

42. Ojo, O. (2009). Impact Assessment Of Corporate Culture On Employee Job Performance. Business Intelligence Journal, 388-397.

43. Omerzel, D. G., Biloslavo, R., Trnavčevič, A., \& Trnavčevič, A. (2011). Knowledge management and organisational culture in higher education institutions. Journal of East European Management Studies, 16(2), 111-139.

44. Oparina, M. E. (2014). Employee Motivation in IT Specialists in the Context of a Dominating Type of Organizational Structure. Social Psychology and Society, 3, 90-103.

45. Saenz Castro, D., Chang Munoz, E., \& Martinez Villavicencio, J. (2016). The impact of organizational culture on the competitive strategy and its influence on the export performance of SMEs in Barranquilla, Colombia. Tec Empresarial, 10(2). 
46. Sajtos, L., \& Mitev, A. (2007). SPSS kutatási és adatelemzési kézikönyv. Alinea Kiadó.

47. Sampaio da Rocha Soares, D. A., Oliva, E. C., de Miranda Kubo, E. K., Parente, V., \& Tanaka, K. T. (2018). Organizational culture and sustainability in Brazilian electricity companies. Rausp Management Journal, 53(4), 488-506. https://doi. org/10.1108/RAUSP-07-2018-0038

48. Sanchez-Baez, E. A., Fernandez-Serrano, J., \& Romero, I. (2020). Organizational culture and innovation in small businesses in Paraguay. Regional Science Policy and Practice, 12(2), 233-247. https:/ / doi.org/10.1111/rsp3.12203

49. Schein, E. H. (1991). What is culture? Reframing organizational culture, pp. 243253). Sage Publications, Inc.

50. Schein, E. H. (1992). Organizational culture and leadership. Jossey-Bass.

51. Schwartz, H., \& Davis, S. (1981). Matching Corporate Culture and Business Strategy. Organizational Dynamics, 10, 30-48. https://doi.org/10.1016/00902616(81)90010-3

52. Senkova, A., Sambronska, K., Mitrikova, J., Matusikova, D., \& Matkova, S. (2016). Corporate culture as a tool for increasing employee motivation. Polish Journal of Management Studies, 13 (2). https:// doi.org/10.17512/ pjms.2016.13.2.13

53. Smola, K. W., \& Sutton, C. D. (2002). Generational differences: Revisiting generational work values for the new millennium. Journal of Organizational Behavior, 23(4), 363-382. https:/ / doi.org/10.1002/job.147

54. Sopoh, G. E., Nzingoula, M. F. K., Jerome, C. S., Ahahanzo-Glele, Y. H., Agueh, V. D., Ouedraogo, L. T., \& Makoutode, M. (2018). Factors associated with the strength of organizational culture in a Beninese hospital. Sante Publique, 30(1), 105-113. https:// doi.org/10.3917/spub.181.0105

55. Soroka, O., Kalaur, S., \& Balendr, A. (2020). Monitoring of Corporate Culture Formation of Specialists of Social Institutions. Postmodern Openings, 11(1), 218233. https:// doi.org/10.18662/po/11.1sup1/131

56. Sporn, B. (1996). Managing University Culture: An Analysis of the Relationship between Institutional Culture and Management Approaches. Higher Education, 32, 41-61. https:/ / doi.org/10.1007/BF00139217

57. Suderman, J. (2012). Using the Organizational Cultural Assessment (OCAI) as a Tool for New Team Development. 4, 7.

58. Tierney, W. G. (1988). Organizational Culture in Higher Education. The Journal of Higher Education, 59(1), 2-21. https:/ / doi.org/10.1080/00221546.1988.11778301

59. Toarniczky, A. (2006). A szervezeti kultúra mérési kultúrája: Kérdőív-tipológia és kulcsdimenziók. Vezetéstudomány / Budapest Management Review, 38, 14-24.

60. Ujhelyi, M., \& Kun, A. I. (2016). Szervezeti kultúra vizsgálata OCAI modellel a Debreceni Egyetem múszaki menedzser hallgatói körében. International Journal of Engineering and Management Sciences, 1, 1-8. https://doi.org/10.21791/ IJEMS.2016.1.46

61. Valent, Á. (2019). Analysis of the motivational factors affecting university choice of ethnic hungarian secondary. Acta Oeconomica Universitatis Selye, 8(2), 68-78.

62. Vasyakin, B. S., Ivleva, M. I., Pozharskaya, Y. L., \& Shcherbakova, O. I. (2016). A Study of the Organizational Culture at a Higher Education Institution [Case Study: Plekhanov Russian University of Economics (PRUE)]. International Journal of Environmental and Science Education, 11(10), 11515-11528.

63. Vlaicu, F. L., Neagoe, A., Tiru, L. G., \& Otovescu, A. (2019). The Organizational Culture of a Major Social Work Institution in Romania: A Sociological Analysis. Sustainability, 11(13), 3587. https:/ / doi.org/10.3390/su11133587 
64. Wisniewski, M., \& Leja, K. (2015). The analysis of organizational culture at the retail sport outlet-The research report. E-Mentor, 3, 56-62. https://doi.org/10.15219/ em60.1188

65. Wolniak, R., Szeptuch, A., \& Ziecina, G. (2017). Analysis of behavior of management in an international metallurgical company, using Cameron and Quinn typology. E-Mentor, 2, 60-69.

66. Wziatek-Stasko, A., Stanzyk, I., \& Stuss, M. M. (2020). Organisational culture as a stress determinant in SME sector organisations. European Journal of International Management, 14(6), 955-975. https:/ / doi.org/10.1504/EJIM.2020.110586

67. Zoghbi-Manrique-de-Lara, P., \& Ding, J.-M. T. (2016). The influence of corporate culture and workplace relationship quality on the outsourcing success in hotel firms. International Journal of Hospitality Management, 56, 66-77. https://doi. org/10.1016/j.ijhm.2016.04.012

\section{Correspondence address:}

Martin Gelencsér, Department of Management and Leadership Sciences, Institute of Economic Science, Hungarian University of Agriculture and Life Sciences, Campus Kaposvár, 40 Guba Sándor street, Kaposvár 7400, Hungary, e-mail: gelencser.martin@ phd.uni-szie.hu

Bence Végvári, Economic and Rural Developmental Engineer, Department of Management and Leadership Sciences, Institute of Economic Science, Hungarian University of Agriculture and Life Sciences, Campus Kaposvár, 40 Guba Sándor street, Kaposvár 7400, Hungary, e-mail: vegvaribence@gmail.com

Assoc. prof. Gábor Szabó-Szentgróti PhD., Department of Management and Leadership Sciences, Institute of Economic Science, Hungarian University of Agriculture and Life Sciences, Campus Kaposvár, 40 Guba Sándor street, Kaposvár 7400, Hungary, e-mail: szabo-szentgroti.gabor@uni-mate.hu 